\title{
Business Angel in the UK: A Review
}

\author{
Yunfei Du \\ School of Language Studies \\ Chongqing University of Technology \\ Chongqing, P.R. China \\ feeba@qq.com
}

\author{
Jiao Xiong \\ School of Vehicle Engineering \\ Chongqing University of Technology \\ Chongqing, P.R. China \\ 3503326@qq.com
}

\begin{abstract}
As business angel becomes a hotpot and an essential financing source to SMEs nowadays, fully understanding business angel could be necessary for the further development of business angel, especially in China. Because of the relatively completed system of angel investment, business angel in the UK is selected to be reviewed. From a macro-perspective, three key components such as networks, government support and approaches to access of business angel in the UK are reviewed. Afterwards, many feasible advices to the further development of business angel are provided in the end.
\end{abstract} review

Keywords-business angel; SMEs; entrepreneurship; financing;

\section{INTRODUCTION}

By contributing to accelerate the economic development and promote job creation, SMEs are considered as one of vital factors of launching the world economy. However, due to the restriction of capital, financing is likely to be considered as determinant whether a SME survive or fail. Gilbey's survey [1] indicates, over $98 \%$ of 800 SMEs in the area of London failed in raising finance, afterwards a huge proportion of them had to choose quit or bankrupt. In that case, for identifying an appropriate way to access funds, researchers and executives had sought sorts of sources which entrepreneurs and SMEs may utilize, such as personal savings, bank loans, and equity (e.g. IPO, venture capital). But it is difficult to access the majority of them due to SMEs' born restrictions, such as low credit, and irregular financial management. As the times require, business angel emerges and invests relatively small scale financial support for enterprises, especially for SMEs, whenever in the start-up, the growing stage or the maturity. It is gradually considered as an appropriate approach of financing for SMEs which could maintain operation and boost growth.

In this context, entirely understanding business angel is assumed to be vital for the further development of business angel, especially in China. It is beneficial to the formation of business angel networks; it is meaningful that entrepreneurs and executives of SMEs could have clear understanding how they can efficiently access funds from business angels; it is effective that the government and policy makers deeply understand business angel and make corresponding policies; it is useful for enhancing the cooperation between business angels and entrepreneurs, which is not only limited in investment, thereby improving ROI of business angels and success rate of SMEs.
In accordance with the relatively complete knowledge system of business angel, networks, government support and approaches to access could be three key components of business angel [2,3].

As a country where business angels had occurred relatively earlier and been a mature financing source, UK is likely to be a good benchmark to measure different perspectives of business angel (even though it is not the best one). With more than 20 years history, there are a big business angel market, a large number of business angels, mature networks, regular principles, and especially a variety of ways to access angels.

The paper starts from an introduction of business angel, including its origin, definitions, traits and irreplaceable functions to SMEs. Afterwards, the main concentration is on UK business angel's mature networks, government support and approaches to access. In the end, it subsequently brings a series of advices.

\section{BUSINESS ANGEL}

\section{A. Classifications of Financing Sources of SMEs}

There are a variety of sources of finance to SMEs. Berry et al. [4] offers an overview of sources of finance and lists a vast number of them, such as banks, leasing and hire purchase, equity, venture capital, and informal venture capital (business angel). Some experts $[5,3]$ synthesize previous researches to improve a relatively rational classification, in which the main sources of finance could be divided into internal finance and external finance. As Lauren Read's research [5] shows, internal finance mainly refers personal savings, loans from families or friends, and re-mortgage, which may be the main sources of funds for SMEs in the initial stage. The remaining sources such as bank overdraft, bank loan, leasing/hire purchase, venture capital, and informal venture capital, could be categorized as external sources.

\section{B. Profile and Attributes of Business Angel}

Based on the above classifications, business angel, the main component of informal venture capital, was originate from Broadway at the end of the 19th century. In the past 100 years, some well-known enterprises such as Amazon, Google, Apple, and Body Shop Chain, were supported by business angels in the initial stage.

Business angels are not enterprises but wealthy individuals who desire to invest in small businesses directly [3]. In Mason 
and Harrison's definition [6], the business angel is stated explicitly as "an individual, acting alone or in a formal or informal syndicate, who invests his own money directly in an unquoted business in which there is no family connection and who, after making the investment, takes an active involvement in the business, for example, as an advisor or member of the board of directors".

Being different from other financing sources, business angel has its unique traits. In the first place, not only do business angels purely pursue for profits, they also follow interests and knowledge to invest. A big part of them indicates that the enjoyment of supporting SMEs and entrepreneurs by sharing their funds, knowledge, skills and social network is a dominant motivation for investment rather than only seeking returns [7]. Besides, the majority of angels prefer to invest in the seed-stage, the start-up, and the early stage because they could play a vital and active role in the enterprise and earn incredible high returns when the enterprise grown up, which is slightly similar to gambling. Thirdly, as similar as venture capitals' interests, they often provide funds to new or high technology firms come from the following sectors: healthcare, biotechnology, software, and electronics. But they also do not reject enterprises from other sectors if potential or possibility of high returns really exists.

\section{Sustained Support for SMEs}

Business angel is a sustained financing source for SMEs because of its huge advantages compared with venture capital, bank loan, and personal savings [2]. Three aspects of business angels in the following present the capability of business angels to sustainably support SMEs.

For earning high returns and being pleasure to take highrisks, the restrictions of funding from business angels are looser than borrowing from banks, accessing financial support from government and being invested by venture capitalist. Thus, it could be one of the easiest approaches for SMEs to acquire funds. Comparing with venture capitalists, business angels do not require too much security of returns, but concentrate on potential of target businesses. In view of it, they are expected to invest a vast number of SMEs in the meanwhile that they have the opportunities to gain more than 10 times, even hundreds of times returns, even though they may fail in a majority of investment. Accordingly, SMEs could benefit from whatever successful or failed collaboration with business angels.

Secondly, business angels could offer more appropriate amount of funds to SMEs than other external finances. As Mason and Harrison's study [8] shows, business angels tend to invest a relatively smaller amount of money than venture capitalists in the UK and the US. There are very few funds that are willing to invest less than $£ 500,000$ in the UK, and venture capitals averagely fund over $£ 1$ million in an early stage business. In comparison, business angels invest relatively small amounts, which is typically less than $£ 100,000$.

Furthermore, business angels invest more than money $[9,2]$. They are likely to share expertise and knack which is the socalled 'smart money' to entrepreneurs they cooperated. Beyond that, their social networks concerning finance including bankers, capitalists, insurance companies, and accountants could be continuously utilized by SMEs in different periods.

\section{BUSINESS ANGEL IN THE UK}

\section{A. Overview of Business Angel in the UK}

With nearly 20 years development, business angels, a vital source of finance for SMEs and entrepreneurial businesses, have been widely accepted by whomever the government, entrepreneurs, executives, or scholars in the UK.

The business angels market in the UK is honored as the most active angel market in Europe. Even though the UK's economy is in recession, the business angel market is still robust and getting bigger. As the single largest source of early stage capital in the UK, private angels invest a huge number of funds between $£ 800$ million and $£ 1$ billion to early stage enterprises each year. Comparably, the number is nearly triple of that in $2009 / 2010$.

According to the survey of UK Business Angels Association, it is estimated that there are about 18,000 angel investors around the country. They may choose different ways of investing [10]. It is a conventional way that a part of them prefer to invest on their own. But the growing trend of investing in groups and forming structured or unstructured syndicates is gradually accepted by increasing investors, since their funds, knowledge and social networks can be combined and shared when making investments. A number of them also participate into nationally or regionally networks. In addition, working with Accelerators, Incubators and investing with Venture Capitals and Co-Investment Funds commonly occur in the recent years. Concerning the size of funding, the majority of deals are in the range of $£ 50,000$ to $£ 500,000$, which is similar to angel investment in other developed countries. Angel investors always fund enterprises in a wide variety of sectors but with a strong technology focus.

For promoting the development of business angels, the UK Government concentrates on supervision and administration of networks and policy support. In that case, UK Business Angels Association has superseded the BBAA (British Business Angel Association) and was re-preformed its new strengthened functions in July 2012, in which some representative members including Beer \& Partners, London Business Angels, and Northwest Business Angels are supervised. Moreover, tax exemption or reduction through EIS (Enterprise Investment Scheme) is also an inventive for involving increasing investors and potential entrepreneurs in the area [10].

\section{B. Business Angel Networks in the UK}

Business angel networks (BANs) in the UK always run on a not for profit basis, which is the bridge to connect business angel investors and entrepreneurs or SMEs. According to the statistics of Mason and Harrison's report [11], the number of members in a network could range from 50 to 200 business angels; at least half of networks are formed as companies or the part of large organizations; most networks have less than 10 employees; the main sources of networks' revenue are from entrepreneurs, angels, success fees, and sponsorships. 
A number of networks operate nationally or regionally while some with a specific sector focus. For example, Northwest Business Angels mainly seeks investment opportunities in the northwest of England whilst Angels Den has ten branches around the UK and three abroad (Singapore, Hong Kong and Qatar) and is likely to receive business plans and organize angels to invest in the entire UK, or even in the worldwide.

Business angel networks provide various types of services. As angels to join the membership, they can share the latest information of investment, interact with fellows or SMEs in pitching events, access to the feasible business propositions, get investment advices, and find other angels to invest in syndicates. Entrepreneurs and SMEs could have the opportunity to access professional advice and support of investment preparation and training, and present business proposition to a large group of angel investors. In the following steps after making an investment agreement, the network may provide legal services to avoid dispute or infringement. The fare of network membership is commonly between $£ 250$ and $£ 750$, but the charge is in diversity between entrepreneurs and investors.

To be illustrated, Angels Den, one of the representative networks with 4000 angels in the UK, is free for angels while the charge of SpeedFunding ${ }^{\mathrm{TM}}$ package which is served to entrepreneurs is $£ 799$, plus $5 \%$ success fee. The latter includes business plan reviewing by an Angels Den expert, circulating to the 4,000 angel network, a pitch school training session, pitching at one SpeedFunding ${ }^{\mathrm{TM}}$ event, arranging follow-up meetings with interested angels, and Edwards Wildman Investment Document Service [12].

\section{The UK Government's Supports for Business Angels}

During the period of business angels developing in the UK, the UK Government plays an irreplaceable role and offers many supports including tax break, the establishment of associations with responsibilities of supervision and administration, and preferential policies to specific sectors or areas.

Tax relief schemes are provided by the UK Government for lightening the risks of angel investors taking and proving the support and encouragement of investing SMEs. There are two main schemes, Enterprise Investment Scheme (EIS) and Seed Enterprise Investment (SEIS), which incent investment from different perspectives. EIS was firstly launched to offer a range of tax relief which is up to $30 \%$ tax break to investors in qualifying SMEs. As expected, this kind of interventions of UK Government positively impacts the enthusiasm of investment in SMEs for a good while. Over $90 \%$ investors were hunting more opportunities of investments [13]. As the raise of business angels, the UK Government launched a new scheme in April 2012, aiming to support angel investors in qualifying businesses in the seed-stage and start-up. According to the rules of SEIS, the tax break of investment in very early stage businesses or businesses in seed rises up to $50 \%$. It could be an efficient complement to EIS for together promoting the development of business angel investment. Combining the benefits and limitations of EIS with SEIS, the comparisons of both schemes are demonstrated in table 3.1 [14].

TABLE I. COMPARISON OF EIS AND SEIS

\begin{tabular}{|c|c|c|c|}
\hline & & EIS & SEIS \\
\hline \multirow{3}{*}{ Benefits } & $\begin{array}{l}\text { Income } \quad \text { tax } \\
\text { relief }\end{array}$ & $\begin{array}{l}30 \text { up to } \\
£ 1,000,000 \text { per } \\
\text { tax year }\end{array}$ & 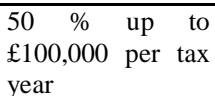 \\
\hline & $\begin{array}{l}\text { Exemption } \\
\text { from capital } \\
\text { gains tax on } \\
\text { disposal of } \\
\text { SEIS shares } \\
\text { after 3 years }\end{array}$ & yes & yes \\
\hline & $\begin{array}{l}\text { Inheritance tax } \\
\text { relief }\end{array}$ & yes & yes \\
\hline \multirow{4}{*}{$\begin{array}{l}\text { Qualifications } \\
\text { and } \\
\text { limitations }\end{array}$} & $\begin{array}{l}\text { Basic } \\
\text { qualifications }\end{array}$ & $\begin{array}{l}\text { 1. not be listed } \\
\text { on the stock } \\
\text { exchange } \\
\text { 2. not under the } \\
\text { control of } \\
\text { another } \\
\text { company }\end{array}$ & $\begin{array}{l}\text { 1. be undertaking } \\
2 . \text { planning to } \\
\text { undertake } \\
\text { 3. a new } \\
\text { qualifying } \\
\text { business }\end{array}$ \\
\hline & Gross assets & $\begin{array}{l}\text { no more than } \\
£ 15 \mathrm{~m} \text { before } \\
\text { investment and } \\
£ 16 \mathrm{~m} \text { afterwards }\end{array}$ & less than $£ 200,000$ \\
\hline & $\begin{array}{ll}\begin{array}{l}\text { Number } \\
\text { employees }\end{array} & \text { of } \\
\end{array}$ & fewer than 250 & fewer than 25 \\
\hline & Others & & $\begin{array}{l}\text { 1. limitation of } \\
\text { rising up to } \\
£ 150,000 \\
2 . \quad \text { specific } \\
\text { requirements of } \\
\text { investors' } \\
\text { relationship }\end{array}$ \\
\hline
\end{tabular}

cited from HMRC, 2012

For promoting the development of business angels, the UK Government concentrates on supervision and administration of networks and policy support. In that case, UK Business Angels Association has superseded the BBAA (British Business Angel Association) and was re-preformed its new strengthened functions in July 2012, in which some representative members including Beer \& Partners, London Business Angels, and Northwest Business Angels are supervised [10]. Moreover, tax exemption or reduction through EIS (Enterprise Investment Scheme) is also an inventive for involving increasing investors and potential entrepreneurs in the area. One of the remarkable supports is encouraging the formation and normalization of business angel networks to enable SMEs access angels and funds more easily.

\section{Accessing Business Angels in the UK}

As an entrepreneur or an executive of a SME, there are a lot of ways of accessing angel investment in the UK. Whilst a part of investors would like to be engaged alone in a deal, accessing through networks and syndicates is a trend and could be increasingly adopted. Accelerator programmes or incubators may be also the choice for accessing. Afterwards, the individual who would like to ask investment need to present his/her business plan to attract investors' interests wherever at live pitching events, showcasing events or online. Generally, it 
could be a more simple way than obtaining funds from venture capitalists or borrowing money from the bank.

In most cases accessing angels through networks is likely to be easier and more convenient to find appropriate angel investors, even though entrepreneurs or SMEs may experience slightly more complex and strict process and afford an amount of fare, compared with directly accessing. Firstly, the 'Gatekeeper' who is an experienced individual receives often approximately 500-1000 business plans each year; screens 50\% to $80 \%$ of them, meets about $150-200$ entrepreneurs, and then decides feasible propositions for showing to investors. Afterwards, business angel networks run regular or irregular pitching events where the selected business propositions can be presented or exhibited. For instance, the local SpeedFunding Events is a regular pitching event which Angels Den runs monthly. If investor members of the network are attracted by a proposition, they can subsequently make decision whether work with the deal alone or participate into a syndicate to invest. In line with the description, it shows a linear procedure in Figure 1.

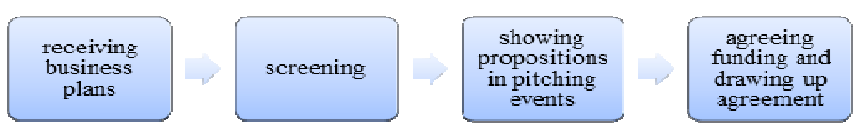

\section{FIGURE I. THE PROCEDURE OF ACCESSING ANGEL INVESTORS THROUGH NETWORKS}

When the angel investors are making the final decision, due to the strengths of avoiding taking the monetary risk alone and sharing knowledge and social networks, it is also a preference of investing in small groups or syndicates on a deal by deal basis. It normally consists of three or more investors wherever in a formal syndicate or an informal one which is temporary formed. The lead angel is selected to coordinate with the entrepreneur/management team and sign final negotiations. But they are separately responsible for their own shares and investment decisions which appear in signing the term sheet and other legal documents respectively.

\section{CONCLUSION}

With the inherent traits of business angel, not only does it plays as an investor, it is also an instructor who could share knowledge, experiences and social network to the funded firm. The function of business angel is well recognized across the world.

From the macro-perspective rather than just limited in individual angels, it reviews business angel in the UK from three essential perspectives of BANs, government support, and accessing approaches by synthesizing the UK's business angel annual reports [15,11], official data, and previous researches. The mature and standardized networks in the UK have specific area or sector focus, and provide a series of services to angels and entrepreneurs. The UK Government engages to the activities of angel investment by offering tax relief (EIS and SEIS), providing preferential policies to specific sector or area, and supervising and administrating angel investment macroscopically. Afterwards, the normal approach of accessing angel investment within a network in the UK could be recognized as a linear procedure, from receiving and screening business plans, showing propositions in pitching events, to agreeing funding and drawing up agreement.

There are some feasible advices to the further development of business angel and for China's business angel. Primarily, some short slabs of business angel such as incomplete networks and associations should be enhanced. On the one hand, it requires executives, institutional investors, angels, especially influential angels increasingly participate in the formation business angel networks which have different specific sector or area focus; existing and prospective networks should provide full-scale services and become more influential. On the other hand, it is necessary that the government engages the supervision and administration of associations. Besides, governments at all levels in China should play a more important role in legal supervision, tax relief and matched services making. In addition, it could be concentrated on the improvement of exit mechanisms, investment capacity of angels, and commercial integrity.

\section{REFERENCES}

[1] Gilbey, K: Programme to Improve Access to Finance for Small Businesses in the Objective 2 Areas of London, Local Economy, 2005, 20(3):309-313

[2] Ramadani, V: Business angels: who they really are, Strategic Change (Formerly Journal of Strategic Change), 2009, 18(8):249-258.

[3] Stokes, D., Wilson, N: Small business management and entrepreneurship. 6th ed., Andover: Cengage Learning, 2010

[4] Berry, A., Citron, D. and Jarvis, R. (1987), 'The informal Needs of Bankers Dealing With Large and Small Companies', Research Report, Number 7, The Chartered Association of Certified Accountants.

[5] Read, L: The financing of small business: a comparative study of male and female business owners, New York: Routledge, 1998

[6] Mason, C.M., Harrison, R.T: Annual Report on the Business Angel Market in the United Kingdom: 2008/09, Department for Business Innovation and Skills 2010, 2010

[7] Macht, S: Business angels offer more than money, [http://www.growingbusiness.co.uk], 2007

[8] Mason, C.M., Harrison, R.T: The Size of the Informal Venture Capital Market in the United Kingdom, Small Business Economics, 2000, 15(2):137-148.

[9] Mason, C.M., Harrison, R.T: Barriers to Investment in the Informal Venture Capital Sector, Entrepreneurship \& Regional Development: An International Journal, 2000, 14(3):271-287.

[10] UK Business Angels Association: [http://www.ukbusinessangelsassociation.org.uk/]

[11] Mason, C.M., Harrison, R.T: Annual Report on the Business Angel Market in the United Kingdom: 2009/10, Department for Business Innovation and Skills 2011, 2011

[12] Angels Den: [http://www.angelsden.com/]

[13] Mason, C.M., Harrison, R.T: Developing Time-Series Data on the Size and Scope of the UK Business Angel Market, Small Business Investment Task Force, BERR: Sheffield, 2008

[14] HM Revenue \& Customs: [http://www.hmrc.gov.uk/]

[15] Mason, C.M., Harrison, R.T: Annual Report on the Business Angel Market in the United Kingdom: 2008/09, Department for Business Innovation and Skills 2010, 2010 